\title{
Epistemic marking in Ika (Arwako) ${ }^{1}$
}

\section{Introduction}

The present paper is a descriptive account of what has been described as subject marking in Ika (ISO 639-3: arh; Arwako-Chibchan, Colombia), but which is better viewed in terms of a typologically unusual pattern called conjunct/disjunct ${ }^{2}$. The analysis of the Ika marking system in terms of conjunct/disjunct prompts a discussion of the functional motivations for this system and at the same time contributes to the wider investigation of the conjunct/disjunct pattern in languages where it has been attested.

Conjunct/disjunct marking consists of a binary contrast where one and the same marker is used with first and second person subjects, in some instances ${ }^{3}$. More specifically, the conjunct marker occurs in statements with first person subjects and in questions with second person subjects. These instances are, at least in the majority of cases, opposed to all other combinations of subject and sentence type (i.e. declarative/interrogative), which are marked as disjunct. The distribution of the forms makes the conjunct/disjunct pattern look like an unusual form of agreement marking. However, from available descriptions of conjunct/disjunct in the literature, this is not supported; neither by the origin of the markers, nor by several of the features relating to their function and distribution (cf. Bickel \& Nichols 2007; Creissels 2009).

In the present paper, it is argued that what has been described as subject marking in Ika (see Landaburu 1992, 2000a; section 4.2, below) should instead be regarded as a variant of the conjunct/disjunct pattern. However, the Ika data also offers new insights into the definition of conjunct/disjunct marking by bringing previously unattested semantics to light. More specifically, the involvement of the addressee seen from the epistemic perspective of the speaker appears crucial in explaining the functional motivations of conjunct/disjunct marking.

It is argued that conjunct marking with first and second person subjects in Ika encodes the speaker's (claim of) direct access to an event. The notion of 'directness' is related to evidential concepts such as first-hand (see Aikhenvald 2004), participatory-factual (Rule 1977; Loughnane 2007), personal-factual (Loughnane 2010), performative (Oswalt 1986) and speaker's

involvement, but differs from all of these to varying degrees (see section 6, below). In the context of Ika, direct access denotes events that are directly perceivable by the speaker, either in terms of attention or memory, and that involve the speaker and/or the addressee. The concept is thus an amalgamation of the intersubjective, epistemic stance of the speaker and his/her sensory/memory access to an event marked as conjunct.

Formally, conjunct/disjunct marking in Ika is defined by a predictable interaction with a set of three sentence-mood markers, -in, $-e$, and $-o$, that are postulated to encode $(a)$ symmetries between the speech participants with regard to the expressed access/non-access central to conjunct/disjunct marking in Ika. Such (a)symmetries are also attested in the closely related

\footnotetext{
${ }^{1}$ The research resulting in the present paper was supported by grants from the Swedish Research Council (2008$668 ; 2011-2274)$.

${ }^{2}$ Examples of other terms used in the literature to discuss near identical instances of conjunct/disjunct (Hale 1980) are egophoric/neutral (Tournadre 1996); locutor/nonlocutor (Curnow 1997); congruent/non-congruent (Dickinson 2000); assertors involvement/assertors non-involvement (Creissels 2009). See Tournadre (2008) for an extensive discussion of the terminology used to describe this phenomena and the appropriateness/non-appropriateness of different labels.

3 'Subject' is used in a functionalist, grammatical sense to denote the $\mathrm{A} / \mathrm{S}$ argument of any predicate relevant to the discussion.
} 
language Kogi where a functionally similar system of complex, epistemic marking has replaced the sentence-mood markers (Bergqvist, in prep.).

Existing proposals for the definition of conjunct/disjunct marking fall short of accounting for the specifics of the system in Ika and formulations of the core functional motivations such as, the "alignment between participant role and grammatical subject" (Creissels 2008) and marking "the informant" (Bickel \& Nichols 2007) cannot account for instances of conjunct marking as well as noted exceptions to the general pattern in the language. Despite these facts, the Ika data supports the canonical pattern of conjunct/disjunct marking found in the literature while at the same time providing important clues, by its noted exceptions, to a more nuanced definition of the pattern's functional motivations.

\section{Comparing the conjunct/disjunct pattern in Kathmandu Newar to Ika}

Ika is spoken in the Sierra Nevada de Santa Marta region of northeastern Colombia. Many aspects of Ika grammar have yet to be explored, but a topic that has been analyzed in some detail is the system for person marking (see Landaburu 1992, 2000a). Jon Landaburu explains "subject" marking in Ika by using the terms intra-locutive and extra-locutive $e^{4}$ to distinguish between two sets of agreement markers. They are exemplified in examples (1)-(4), below:

(1) bunsi-w-iN

spin.yarn-INT-DECL

'I am spinning yarn.'

(2) na-bunsi-kw-e 2SG-spin.yarn-INT-SUSP

'Are you spinning yarn?'

(3) bunsa-y-iN

spin.yarn-EXT-DECL

'He is spinning yarn.'

(4) bunsi-Ø-e

spin.yarn-EXT-SUSP

'Is he spinning yarn?'

(ibid. 9-10 [my translation and glossing)

In examples (1)-(4), the intra-locutive $-k w /-w$ is used with first and second person and the extralocutive $-y /-\emptyset$ marks third person. Intra-locutive marking thus refers to the speech participants and extra-locutive marking for non-speech participants. Landaburu's analysis of subject marking in terms of intra-and extra-locutive is, however, problematic and gives rise to some inconsistencies that are discussed in Section 4.2. The most problematic contradiction is the fact that second person subjects take the extra-locutive marker in statements:

\footnotetext{
${ }^{4}$ L'intralocutif vs. l'extralocutif (Landaburu 1992: 8). The glossing used with these labels are INT and EXT to denote intra-locutive and extra-locutive, respectively.
} 
(5) nə-bunsa-y-iN

2SG-spin.yarn-EXT-DECL

'You are spinning yarn.'

As stated, the present paper attempts to analyze "subject" marking in Ika in terms of conjunct/disjunct marking as an alternative to Landaburu's analysis. It is argued here that viewing "subject" marking in Ika as conjunct/disjunct marking, solves the observed contradictions of Landaburu's description and better accounts for the distribution and function of the $-k w /-w$ and the $-\varnothing /-y$ markers (see section 5 and 6 , below).

The very first description of the conjunct/disjunct pattern was Austin Hales's account of the Sino-Tibetan language Kathmandu Newar (Hale 1980), where the terms conjunct/disjunct were also first used in this sense. Consider the data in (6)-(9), below, where $-\bar{a}$ is conjunct and $-a$ is disjunct with the verb wane, 'go' in the past tense:

(6) Ji ana wan $\overline{\boldsymbol{a}}$

1SG there go.CONJ

'I went there.' (conjunct)

(7) Cha ana wan $\overline{\boldsymbol{a}} \quad l \bar{a}$

2SG there go.CONJ INTERR

'Did you go there?' (conjunct)

(8) Cha ana wana

2SG there go.DIS

'You went there.' (disjunct)

(9) Wa ana wana

3SG there go.DIS

'He went there.' (disjunct)

(ibid: 95)

In terms of simple pattern-matching, it is clearly possible to match the intra-locutive marker in Ika to conjunct marking in Newar as well as the extra-locutive to the disjunct marker, in comparing examples (1)-(5) to examples (6)-(9). This mapping is the starting point for the following argument that occupies Sections 5 and 6 , but the complete picture of how the $-k w /-w$ and the $-\varnothing /-y$ markers are distributed and what conditions some noted exceptions, requires a more detailed discussion.

\section{Conjunct/disjunct}

Before going into the details of the Ika marking system, a brief look at some existing descriptions and definitions of conjunct/disjunct marking will benefit the ensuing discussion. Conjunct/disjunct were, originally, terms used in the co-reference between subjects (i.e. comparable to logophoric reference) to denote an alignment/non-alignment of subjects between 
clauses, found in e.g. indirect quotation ${ }^{5}$. Conjunct signals subject alignment: $\mathrm{He}(i)$ says that he(i) would like to play the piano more often. Disjunct corresponds to a non-alignment of subjects, $\mathrm{He}(i)$ says that he(j) should learn how to play the piano.

Separate analyses proposed for languages that display a version of the conjunct/disjunct system point to differences with regard to the specific grammatical circumstances and the motivational functions that has resulted in such systems. However, in addition to differences between languages, there are also common features that appear central to any language that has a version of the conjunct/disjunct system.

The crucial features are: the general requirements for conjunct marking to occur in the language; the origin and meaning of the markers in the context of the overall grammatical structure of the language; noted exceptions to the systematicity of conjunct/disjunct marking.

In some languages, conjunct marking is only attested with agentive or controlled verbs (e.g. Creissels 2008, 2009 for Akhvakh) but other languages pay less heed to this restriction (e.g. Curnow 2002 for Awa Pit). Creissels (2009) argues that conjunct/disjunct systems "show variation in the particular type of [subject] involvement" that determines the choice between conjunct and disjunct marker (ibid. 10). Awa Pit would be characterized as having a broad notion in this regard, while a language such as Akhvakh and Newar have a narrower one (see below).

In Lhasa Tibetan (DeLancey 2001) and Standard Spoken Tibetan (Tournadre 1996), conjunct marking is not exclusive to first- and second person subjects. The sufficient connection between subject and grammatical role in the latter, can be as argument, possessor or as an otherwise interested person (ibid. in Bickel 2008: 4). There are however differences between forms where the scope may be narrower, as with the conjunct marker, yin, which requires the subject to be a volitional agent.

DeLancey argues that conjunct/disjunct markers in Lhasa Tibetan are grammaticalized mirative markers that encode a difference between assimilated and non-assimilated information. This proposal is critiqued in Curnow (2000) where distributional facts of mirative- and conjunct/disjunct systems, and examples from languages such as Tsafiki and Awa Pit, are used to argue against this path of grammaticalization in a broader typological perspective.

In Northern Akhvakh, two forms: -ada (conjunct) and -ari (disjunct) imply direct knowledge of an event (Creissels 2009: 13). The use of -ada is limited to controllable events rather than ones encoding agency and volition on behalf of the subject. Creissels makes a case for the origin of the markers in terms of a reanalysis of already available TAM distinctions, rather than as a grammaticalization of pronoun forms. He considers the system to be a recent invention, a fact that coincides with DeLancey's analysis of Lhasa Tibetan, although the two systems, of course, have distinct origins.

Creissels argues that the version of conjunct/disjunct found in Northern Akhvakh encodes an "alignment of argument roles and speech act roles", but that "the relevant distinction at the level of speech act roles cannot be formulated in terms of person only." (Creissels 2008: 317). Thus, conjunct/disjunct marking in Akhvakh is clearly not a system for person marking per se, although there are aspects of such a system in the distribution and function of conjunct/disjunct markers. Some variation is reported to the prototypical case of conjunct/disjunct marking (termed "assertors involvement" in Creissels' 2009 analysis), but then only results in "stylistic variation" and is thus not part of the analysis, but rather seen as exceptions to the pattern.

\footnotetext{
${ }^{5}$ The use of conjunct/disjunct to denote the alignment between participant role and subject, i.e. speaker and first person subject, has been criticized (cf. Tournadre 2008) and several competing terms have been introduced to describe near identical patterns in other languages than Newar (see below).
} 
In Tsafiki (Barbacoan, Ecuador), the markers - $y o$ (conjunct) and $-i$ (disjunct) are termed congruent and noncongruent, respectively (Dickinson 2000). Their use and meaning can be compared to the system found in Lhasa Tibetan in terms of the mirative semantics present in both systems and Dickinson's analysis as a "theory of conscious experience" mirrors DeLancey's analysis in terms of prepared and unprepared minds to a large degree. The analysis of Tsafiki is largely based on conjunct marking with first person subjects, but this is commonly the case for any description of conjunct/disjunct systems, anyway.

Of all available descriptions of conjunct/disjunct systems, Awa Pit (Curnow 2002) is the most deviating given the number of forms involved and the quite unrestricted distribution of these in the contrasting semantic roles of actor and undergoer.

There is a formal separation between present and past tense with two conjunct forms in the past paradigm, $-w$ (conjunct subject) and $-s$ (conjunct undergoer), and one disjunct form, $-z i$. The conjunct forms $-w$ and $-s$ are, however, not always separated by semantic role (i.e. actor/undergoer). With intransitive verbs, they are in what appears to be free variation with some yet unidentified semantic difference. In addition, conjunct/disjunct forms are also present with some non-verbal elements, which is another feature that sets Awa Pit apart from other attestations of the system in terms of combinatory possibilities between conjunct markers and grammatical constituents (cf. Curnow 2002: 623). Awa Pit features neither mirativity nor agency/control as motivations for conjunct marking in the language.

The result of analyzing the Ika data in the following sections contrasts with the functional motivations proposed as part of the analyses of conjunct/disjunct marking above. Most importantly, conjunct marking in Ika is not used with second person subjects in formal/"information-seeking" questions, as one would expect from previous descriptions of conjunct/disjunct systems. We will turn to the specifics of the system in Ika after having established the basic features of conjunct/disjunct marking in the language.

\section{The verb and "subject" marking in Ika}

In this section, we take look at some basic features of the Ika verb phrase. This is done in order to facilitate the following discussion of the details of what is called "subject" marking in Ika, until we are ready to label it otherwise. The issue of labeling is always challenging and in this case there is an added dimension of complexity, since what on the surface appears to be subject marking, should in fact be regarded as something else entirely (i.e. as conjunct/disjunct marking). In the glossed examples of Section 4.1, I will use SUBJ as a gloss for all "subject" markers, which in Sections 5 and 6 are glossed as either CONJ (conjunct) or DIS (disjunct), depending on which specific form they refer to. An added complicating factor in discussing the semantic and grammatical features of Ika "subject" markers, is the analysis that Landaburu $(1992,2000$ a) proposes using the terminology intra-locutive and extra-locutive that was mentioned in the introduction. In Section 4.2, "subject" marking is glossed using these labels in the form of INT and EXT, respectively in keeping with Landaburu's choice of terminology.

\subsection{The verb in Ika}

Ika is head-marking with SOV word order and the verb is inflected for person, tense, aspect and sentence mood according to two schemas; one for single-verb constructions (10a) and another for auxiliary, two-part constructions (10b). 
(10) a. $\quad \pm$ subject/object+[VERB+tense]+"subject"+sentence mood

b. $\quad \pm$ subject/object+[VERB+tense]+("subject")+aspect/aktionsart

$[$ AUX+tense]+("subject")+sentence mood

Prefixed subject/object marking is not obligatory and appears to be used as a disambiguating device that partly depends on the suffixed "subject" marker but also on pragmatic factors. The third person prefixed subject marker is posited as a null-morpheme. Suffixed "subject" markers are obligatory, although they also are null-morphemes in some instances (see Section 5), and can occur alternately with the auxiliary or the main verb in auxiliary constructions, which is why they are put in parenthesis.

Tense marking appears as an alteration to the verb stem and combines with a change in "subject" marking, contrasting past with non-past forms ${ }^{6}$. This change to the verb stem also applies to auxiliaries (see Section 5, below).

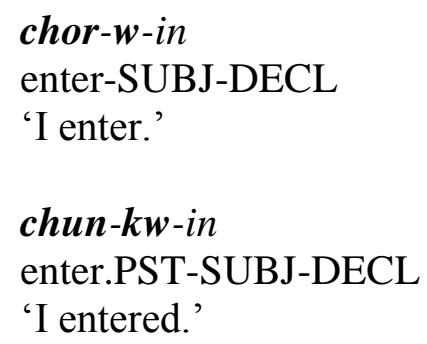

(Landaburu 2000: 742)

However, a temporally conditioned change in "subject" marking from $-w$ to $-k w$ only applies to constructs with first person subjects. Verbs inflected for second person subjects take the $-k w$ suffix regardless of temporal context, which means that there is a grammatical pattern underlying the distribution of $-w$ and $-k w$ that cannot be attributed to temporal perspective. As it turns out, the exclusive use of $-w$ with first person subjects and the shared use of $-k w$ with both first and second person subjects, depending on sentence type, supports the argument presented in Section 6 with regard to the underlying semantics of "subject" marking in Ika as conjunct/disjunct. Its discussion, however, will be postponed until then.

Suppletive verb forms are also used in what appears to be a distinction between single-verb (13) vs. auxiliary constructions (14).

$$
\begin{array}{ll}
\text { (nän) } & \boldsymbol{z} w \boldsymbol{w} \boldsymbol{i}-k w-i n \\
\text { 1SG } & \text { go-SUBJ-DECL } \\
\text { 'I went.' } &
\end{array}
$$

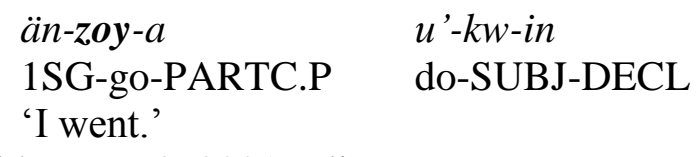

\footnotetext{
${ }^{6}$ An exception to this rule is found with the verb $n a k$, which in its inflected form $n a$ ' is followed by $-k(w)$ in both past and non-past contexts. I take this exception to be phonologically conditioned.
} 
There is an aspectual participial marking on the main verb in auxiliary constructions that has been analyzed in terms of imperfective vs. perfective marking (Landaburu 2000: 742). This participial marking is also connected to the choice of auxiliary verb, where perfective $-a$ combines with $a w$ - ('do') and nik- ('change') and imperfective -än combines with nuk- ('be'). Compare the two examples below, where (15) exemplifies the perfective and (16) the imperfective with respective auxiliaries:

$$
\begin{array}{ll}
\text { a-zoy-a } & \boldsymbol{u}-y-e \\
\text { 3SG-go-PARTC.P } & \text { do-SUBJ-SUSP } \\
\text { 'Did he go?' } &
\end{array}
$$

$\begin{array}{ll}\text { ei } \text { chuw- ̈̈n } & \boldsymbol{n u} 7-k w \text {-in } \\ \text { this see/watch-PARTC.IMP } & \text { be-SUBJ-DECL }\end{array}$

'I'm looking at it.'

(Ika Field Notes_090821_Eli)

There are three sentence mood suffixes, namely -in, 'declarative', $-e$, 'suspensive' and - $o$, 'interrogative'. The precise semantics of the sentence mood markers remains to be defined (see below, Sections 5 and 6) but distribution-wise, -in is found with declarative statements and - $e$ and - $o$ with "questions" (but see Section 6, below). The 'suspensive' marker - $e$ appears to indicate some uncertainty on behalf of the speaker and many constructions involving this marker look like straight forward questions:

$$
\begin{array}{ll}
m a & n \ddot{a}-z w e i-k w-\boldsymbol{e} \\
\text { 2SG.IND } & \text { 2SG-go-SUBJ-SUSP }
\end{array}
$$

'Are you going?'

(Ika Field Notes_090821_Eli)

The semantics of the sentence mood markers have special relevance for the present investigation and will be discussed in some detail. For further information on matters of the grammar and the phonology of Ika, I refer the reader to Landaburu (2000a).

An aspect of the present introduction to the verb in Ika that will remain tentative awaiting further research is whether there are important semanto-pragmatic differences between singleverb and auxiliary constructions. It may be a discourse related choice to use one or the other, as Landaburu (2000) suggests, or it may depend on yet unidentified motivations. Now we turn briefly to Landaburu's account of "subject" marking in Ika before returning to analyzing the same system as conjunct/disjunct in Section 5.

\subsection{Subject marking in Ika according to Landaburu (1992)}

As stated in the introduction, Landaburu (1992, 2000a) analyzes the system for "subject" marking in Ika and argues for a formal separation between intra-locutive and extra-locutive forms, which corresponds to a separation between first/second vs. third person subjects, although the focus of Landaburu's description is on first and third person subject forms. The intra-/extralocutive paradigm is formally contrasted to the "object" prefixes (cf. Landaburu 2000: 740; Section 4.1 , above). 
The intra-locutive form is according to Landaburu $-k w /-w /-k$ and the extra-locutive is $-y /-\varnothing$, depending on the phonological context. The separation into intra- and extra-locutive forms is displayed in the two tables below, which are reproduced from Landaburu (1992). There, the example phrases are segmented by morpheme according to the following schema: verb"subject"-sentence mood.

\begin{tabular}{|c|c|c|c|c|c|}
\hline ROOT & INT+DECL & INT+SUSP & INT+INTERR & EXT+DECL & EXT+INTERR \\
\hline $\begin{array}{l}\text { chon- } \\
\text { 'enter' }\end{array}$ & $\begin{array}{l}\text { chor-w-in } \\
\text { 'I enter.' }\end{array}$ & $\begin{array}{l}\text { chor-w-e } \\
\text { 'Do I enter?' }\end{array}$ & $\begin{array}{l}\text { chóna-k-o } \\
\text { 'Do I enter?' }\end{array}$ & $\begin{array}{l}\text { chónə-y-in } \\
\text { 'He enters.' }\end{array}$ & $\begin{array}{l}\text { chon- } \boldsymbol{\emptyset} \text {-o } \\
\text { 'Does he enter?' }\end{array}$ \\
\hline $\begin{array}{l}\text { nak- } \\
\text { 'arrive' }\end{array}$ & $\begin{array}{l}n a^{\prime}-\boldsymbol{k} \boldsymbol{w} \text {-in } \\
\text { 'I arrive.' }\end{array}$ & $\begin{array}{l}n a^{\prime}-\boldsymbol{k} \boldsymbol{w}-\boldsymbol{e} \\
\text { 'Do I arrive?' }\end{array}$ & $\begin{array}{l}\text { nákə-k-o } \\
\text { 'Do I arrive?' }\end{array}$ & $\begin{array}{l}\text { nákə-y-in } \\
\text { 'He arrives.' }\end{array}$ & $\begin{array}{l}\text { nak- } \boldsymbol{\emptyset}-o \\
\text { 'Does he arrive?' }\end{array}$ \\
\hline $\begin{array}{l}\text { buns- } \\
\text { 'spin.yarn }\end{array}$ & $\begin{array}{l}\text { bunsi-w-in } \\
\text { 'I spin.' }\end{array}$ & $\begin{array}{l}\text { bunsi-w-e } \\
\text { 'Do I spin?' }\end{array}$ & $\begin{array}{l}\text { búnsa-k-o } \\
\text { 'Do I spin?' }\end{array}$ & $\begin{array}{l}\text { búnsa-y-in } \\
\text { 'He spins.' }\end{array}$ & $\begin{array}{l}\text { buns- } \emptyset \text {-o } \\
\text { 'Does he spin?' }\end{array}$ \\
\hline 'sam- & $\begin{array}{l}\text { kama-w-in } \\
\text { 'I sleep.' }\end{array}$ & $\begin{array}{l}\text { kama-w-e } \\
\text { 'Do I sleep?' }\end{array}$ & $\begin{array}{l}\text { kama-k-o } \\
\text { 'Do I sleep?' }\end{array}$ & $\begin{array}{l}\text { kama-y-in } \\
\text { 'He sleeps.' }\end{array}$ & $\begin{array}{l}\text { kam- } \emptyset \text {-o } \\
\text { 'Does he sleep?' }\end{array}$ \\
\hline
\end{tabular}

Table 1. Subject conjugation in the present tense (after Landaburu 1992 [my translation and morpheme segmentation]). INT = intra-locutive, $\mathrm{EXT}=$ extra-locutive

\begin{tabular}{|c|c|c|c|c|c|}
\hline ROOT & NT+DECL & INT+SUSP & EXT+DECL & EXT+SUSP & EXT+INTERR \\
\hline $\begin{array}{l}\text { chon- } \\
\text { 'enter' }\end{array}$ & & $\begin{array}{l}\text { chun-kw-e } \\
\text { 'Did I enter?' }\end{array}$ & $\begin{array}{l}\text { chona-y-in } \\
\text { 'He entered.' }\end{array}$ & $\begin{array}{l}\text { chona-y-e } \\
\text { 'Did he enter?' }\end{array}$ & $\begin{array}{l}\text { chun- } \emptyset \text {-ko } \\
\text { 'Did he enter?' }\end{array}$ \\
\hline $\begin{array}{l}\text { nak- } \\
\text { 'arrive' }\end{array}$ & & $\begin{array}{l}n a^{\prime}-\boldsymbol{k} \boldsymbol{w}-\boldsymbol{e} \\
\text { 'Did I arrive?' }\end{array}$ & $\begin{array}{l}\text { naka } \\
\text { 'He a }\end{array}$ & $\begin{array}{l}\text { naka } \\
\text { 'Did }\end{array}$ & $\begin{array}{l}\text {-ko } \\
\text { he arrive? }\end{array}$ \\
\hline $\begin{array}{l}\text { buns- } \\
\text { 'spin.yarn }\end{array}$ & $\begin{array}{l}\text { bunsi } \\
\text { 'I spu }\end{array}$ & $\begin{array}{l}\text { bunsi-kw-e } \\
\text { 'Did I spin?' }\end{array}$ & $\begin{array}{l}\text { buns } \\
\text { 'He a }\end{array}$ & $\begin{array}{l}\text { bunsi } \\
\text { 'Did }\end{array}$ & $\begin{array}{l}\text { bunsi-Ø-ko } \\
\text { 'Did he spin?' }\end{array}$ \\
\hline$\frac{\mathrm{k \partial m-}}{\text { 'sleep' }}$ & $\begin{array}{l}\text { kama-kw-in } \\
\text { 'I slept.' }\end{array}$ & $\begin{array}{l}\text { kama-kw-e } \\
\text { 'Did I sleep?' }\end{array}$ & $\begin{array}{l}\text { kəma-y-in } \\
\text { 'He slept.' }\end{array}$ & $\begin{array}{l}\text { kama-y-e } \\
\text { 'Did he sleep?' }\end{array}$ & $\begin{array}{l}\text { kama-Ø-ko } \\
\text { 'Did he sleep?' }\end{array}$ \\
\hline
\end{tabular}

Table 2. Subject conjugation in past tense (after Landaburu 1992 [my translation and morpheme segmentation]).

There are, however, obvious problems with the interpretation of the $-k$ suffix (table 1 , row 4 ) as an instantiation of the intra-locutive marker. Since the same - $k$-suffix is found with third person interrogative constructions (table 2 , row 6 ) in the form of $-k o$, this interpretation results in a contradiction. If Landaburu's proposed separation into intra-locutive and extra-locutive is to be maintained, then the $-k$, as an intra-locutive suffix, cannot occur with the interrogative $-o$ in third person, which should be accompanied by an extra-locutive form. This inconsistency will be discussed in detail in the following section.

Another feature of Landaburu's account is that he reports it to be nearly impossible to produce second person statements with intra-locutive marking ${ }^{7}$, an observation that appears troublesome in the context of intra-/extra-locutive marking. If indeed, $-k w /-w /-k$ is an intralocutive marker, referring to the speech participants, one would expect to find it in declarative statements with second person subjects, too. Instead, second person subjects appear to map onto third person subjects, rather than first person ones, as exemplified below:

\footnotetext{
${ }^{7}$ Landaburu even considers the possibility that intra-locutive marking is ungrammatical with second person subjects (Landaburu 2000a: 743).
} 
chu-a

see-PARTC.P

'I saw it.'

(19)

(20) nə-chu-a

2SG-see-PARTC.P

'You saw it.'

chu- $a$

see-PARTC.P

'He saw it.' $n a r-\boldsymbol{w}-a$

be-INT-PERF

$n a-\varnothing$

be.PERF-EXT

$n a-\varnothing$

be.PERF-EXT (ni)

DECL

(ni)

DECL

(ni)

DECL

(Frank 1990:51 [my adjusted glossing and orthography])

The complete picture of "subject" marking in Ika must account for the presence/absence of $-k w /-$ $w /-k$ in declarative and interrogative sentences with second person subjects. Recent field work by this author has resulted in data that clarifies how "subject" marking is made in this regard.

\section{Conjunct/disjunct marking in Ika}

The hypothesis argued for in this and the following sections is that the $-(k) w$-suffix in Ika is conjunct and that $-y /-\varnothing$ is disjunct. Although the examples discussed so far (see Section 1; examples 18-20, above) seem to align with such a hypothesis, there are issues raised by Landaburu's analysis that need to be considered for the argument to hold.

First, questions with first person subjects are, according to Landaburu, possible using the intra-locutive $-k w /-w /-k$, a fact that would be contradictory to the conjunct/disjunct alignment, where such constructions are marked as disjunct, corresponding to the extra-locutive form, $-y /-\varnothing$. There are two "interrogative" constructions, namely ones with the 'suspensive', $-e$ and the 'interrogative', - $o$ (see tables 1 and 2, above). As noted in section 4.2 above, Landaburu argues that the $-k$ suffix found together with the interrogative $-o$ is a variant of the intra-locutive suffix. Given that the resulting - $k o$ suffix is found with both first and third person questions, this is something that results in a contradiction. Consider the examples in (21) and (22):

$$
\begin{aligned}
& \text { búnsa-k-o } \\
& \text { spin.yarn-INT-INTERR } \\
& \text { 'Do I spin?' } \\
& \text { spin.yarn-INT-INTERR } \\
& \text { 'Did he spin?' }
\end{aligned}
$$

(Landaburu 2000a: 742 [glossing and translation after Landaburu's analysis]).

According to the analysis proposed here, it is a mistaken assumption to regard $-k$ as an intralocutive marker in Landaburu's terms, and it cannot be a conjunct marker either. The - $k o$ suffix 
should be regarded as a phonologically conditioned variant of the - $o$ suffix when the verb ends in a vowel ${ }^{8}$.

However, the fact that $-(k) o$ is found with both first and third person questions conforms to expectation when analyzed as conjunct/disjunct. There, questions with first person subjects are formed like those for third person subjects, namely as disjunct:

eiy chú-Ø-ko

this see-DIS-INTERR

'Did he see it?'

eiy chuá-Ø-ko

this see.PERF(?)-DIS-INTERR

'Have I seen it?'

(Ika Field notes 090823_Eli)

Related to the issue of conjunct marking with interrogative constructions, is the analysis of first person subjects that combine with the 'suspensive' suffix $-e$. These combinations pose a problem to the present argument, especially since the $-e$ suffix, in fact does combine with the conjunct marker $-(k) w$, thus contradicting the stated facts of the conjunct/disjunct system, where first person questions are marked as disjunct.

In checking such sentences with speakers in the field, however, I was told that the construction in (26) is not semantically equivalent to one with a second person subject, as seen in (25):

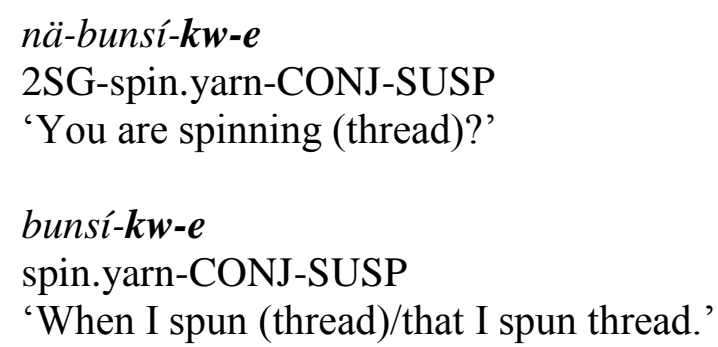

From the translation, example (26) looks like a non-finite complement. However, the example in (26) can appear on its own according to the speaker who produced it. Formally, it is also a finite verb phrase given that it is inflected for conjunct/disjunct and sentence mood. An example that was provided as an illustration of how the example in (21) can be used confirms the status of the verb phrase as finite.

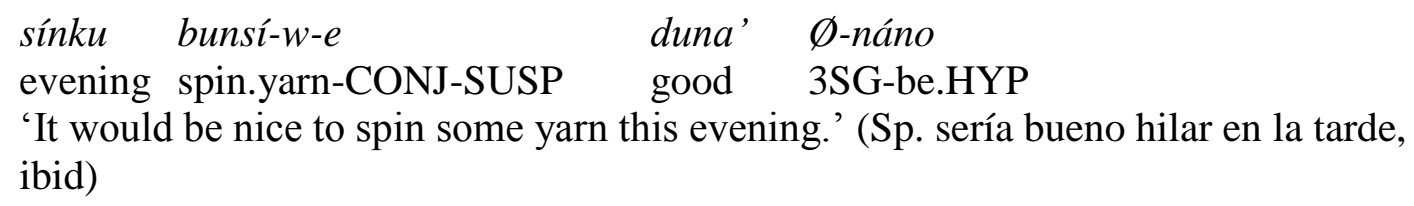

\footnotetext{
${ }^{8}$ There are a few noted exceptions to this proposal. It appears that nasals and glides also can be followed by the $-k o$
} suffix in some instances. 
The example in (27) has the speaker as subject as evidenced by the presence of the conjunct marker and the absence of the second person subject prefix än- on the verb (bunsi-). duna' náno ('it would be nice.') occupies the sentence-final slot where one commonly finds the finite verb. However, these two verb phrases must be regarded as juxtaposed from the fact that they both are inflected for sentence mood (i.e. $-e$ and no, respectively ${ }^{9}$ ) thus supporting the view of bunsi $(k)$ we as an independent verb phrase. A complex verb phrase with a finite verb and a non-finite compliment does not allow two separate inflections for sentence mood, nor person. The explanation for the change in meaning between first and second person conjunct in combination with $-e$ is addressed in Section 6, below.

The presence of conjunct marking with first person interrogative constructions is reported by Curnow (2002) for Awa Pit. In that language, when the conjunct marker is used in questions with first person subjects, the resulting phrase is rhetorical, i.e. the subject/speaker knows the answer to the question that he poses to himself. In Ika, the combination of a first person subject (i.e. conjunct) with the suspensive $-e$ does not result in a rhetorical question.

Another issue that also needs clarification in order to justify the analysis of conjunct/disjunct marking in Ika is that questions with second person subjects can be marked as both conjunct and disjunct:

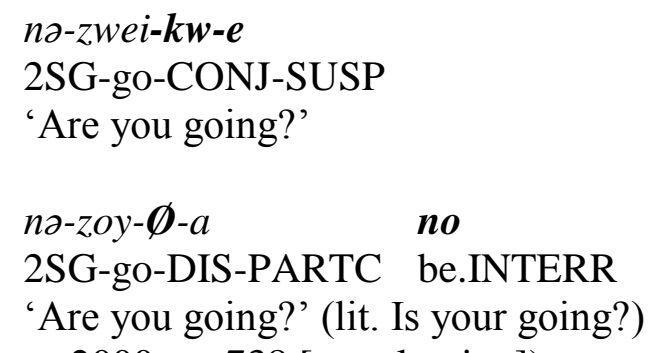

Although the translations in (28) and (29) give both sentences the appearance of questions, there are distinct differences in meaning between $-e$ and $-(k) o$. One difference is demonstrated by combining the $-e$ suffix with first person subjects, as we saw above, which suggests that $-e$ does not encode a question.

There is also a semantic difference between using $-e$ and $-o$ with disjunct marking that conveys a difference in temporal perspective:

$$
\begin{array}{ll}
k ə m ə-y-a & \text { no } \\
\text { sleep-DIS-PARTC } & \text { be.INTERR } \\
\text { 'Is he asleep?' } &
\end{array}
$$

\begin{tabular}{|c|c|}
\hline & $\begin{array}{l}\text { kamə-y-a } \\
\text { sleep-DIS-PARTC }\end{array}$ \\
\hline
\end{tabular}

(Landaburu 2000a: 742)

\footnotetext{
${ }^{9}$ Combining the auxiliary $n a$ with the "interrogative" no results in a 'hypothetical' meaning that cannot be attributed to either element, but is a result of their combination.
} 
Note that $-e$ does not carry semantics relating to tense by itself, since it can appear in both present and past contexts, something that also goes for $-o$, which also lacks restrictions with regard to temporal context (see tables 1 and 2, Section 4.2).

The stem alterations found with main verbs depending on temporal perspective are also found with auxiliary verbs such as no/nar-e, which also encode temporal-aspectual information. Landaburu (2000: 742) contrasts $n i$ ('declarative-present') with nar-in ('declarative-past'), and no ('interrogative-present') with nar-e ('interrogative-past'). The use of auxiliary verbs as temporal-aspectual operators is also reported by Trillos Amaya (1999) for the closely related language Damana, supporting Landaburu's analysis for Ika.

There are no indications that $-i n,-e$, or $-o$ as suffixes are different semantically from their combination with auxiliaries in $n i$, nare, and no. It is the auxiliary construction that signals a temporal change, not the suffixes themselves. The semantic difference between $-e$ and $-o$ must be explained by other means than time semantics.

We will postpone the explanation of the variability of conjunct marking with second person "questions" and the semantic contrast between - $e$ and - $o$ for now, and leave it for Section 6 where an attempt is made to explain the motivations for conjunct/disjunct marking in Ika and all its component parts. Instead of being obstacles to the present hypothesis these issues involving - $e$ and $-o$ turn out to be important pieces of the puzzle to explain conjunct/disjunct marking in the language.

In other respects, Ika conforms to expectation when compared to conjunct/disjunct systems found in languages like Newar and Akhvakh in that conjunct marking is used with "active" verbs in some sense. Hale states that, "finite conjunct forms are appropriate only where the actor of the clause is portrayed as true instigator, one responsible for an intentional act:" (Hale 1980: 96). While a complete mapping of conjunct/disjunct forms with all Ika verbs remains to be worked out, there are some indications on how conjunct forms combine with different verbs. Intransitive and transitive verbs alike, e.g. nak ('come'), $c h w$ - ('see'), and $k w a$ ('live') are conjunct with first person subjects in accordance with the criteria relevant for the conjunct/disjunct system. The already mentioned variability with second person subjects is not related to differences in terms of agency/control and will be discussed in the following section. Transitive verbs may also mark the subject using disjunct marking, thereby confirming that the choice between conjunct and disjunct does not depend on transitivity or the grammatical role of agent:

$$
\begin{array}{lll}
\text { no-nive- 'zasana } & (k i) & u-y-e \\
\text { 2SG-1PL-pay } & \text { (CNT) do-DIS-SUSP } \\
\text { Did you pay us?' (Frank 1990: } 65 \text { [my adjusted glossing]) }
\end{array}
$$

\begin{tabular}{|c|c|c|}
\hline & $\begin{array}{ll}\text { bunsa-mä } & \text { eiy } \\
\text { spin varn-PARTC DEM }\end{array}$ & $\begin{array}{l}\text { mi-gunk- } \boldsymbol{\emptyset}-o \\
\text { 2SG-know-DIS-INTERR }\end{array}$ \\
\hline
\end{tabular}

There are a several verbs that are never marked as conjunct, namely verbs having to do with the inner states of the subject, such as 'know', 'feel', 'think', 'like', and 'want/desire':

'Do you know how to spin thread?' (Ika Field notes 090822_Eli) 
b mi-gaNkun- Ø-a no

2SG-know-DIS-PARTC.P INTERR

'Do you know (it)?' (Landaburu 2000a:740)

Examples of other verbs that are unavailable for conjunct marking are, 'vomit' and 'snore', while a verb like 'faint'/'pass out' can combine with conjunct marking.

In summarizing so far, the features that favor an analysis of "subject" marking in terms of conjunct/disjunct marking are stated as the following: 1) first person declarative clauses (i.e. with $-i n / n i)$ and second person "suspensive" clauses (i.e. with $-e$ ) take the $-(k) w$ marker. This marking is contrasted to other combinations of subject-person and clause type which take the $-\emptyset /-y$ marker. An exception is that first person subjects marked as conjunct can combine with the "suspensive" $-e$ suffix. This combination does, however, not yield the same semantics as the ones with second person subjects; 2) questions formed with the - $(k) o$-suffix combine with the disjunct marker to denote first and third person subjects, equally. The exception here is that second person subjects also take the $-(k) o$ suffix, which regardless of subject-person always is disjunct. 3) Third person subjects only take the disjunct $-\varnothing /-y$ marker, regardless of clause-suffix.

The two exceptions to the conjunct/disjunct pattern that have been noted in this section, namely that first person subjects marked as conjunct combine with the $-e$ suffix, and that second person subjects marked as disjunct take the $-(k) o$ suffix, will be explained in the following section.

\section{Conjunct marking: encoding the speaker's immediate access to an event}

In this section we will look closer at the grammatical effects of conjunct/disjunct marking in Ika and what these can tell us about the properties of the conjunct/disjunct pattern itself.

Two issues are at the core of the discussion, namely the semantic consequences of conjunct/disjunct marking with first and second person and the role of "interrogation" in this system. These issues were introduced in the preceding section, but since the objective there was to establish that conjunct/disjunct is indeed a grammatical pattern that is present in Ika, a discussion of the specifics of the system, including its irregularities, is left for the present section to deal with.

Firstly, conjunct marking with second person subjects is understood by speakers as 'present', while a switch to the disjunct marker $-y /-\varnothing$ means that the event is 'past'.

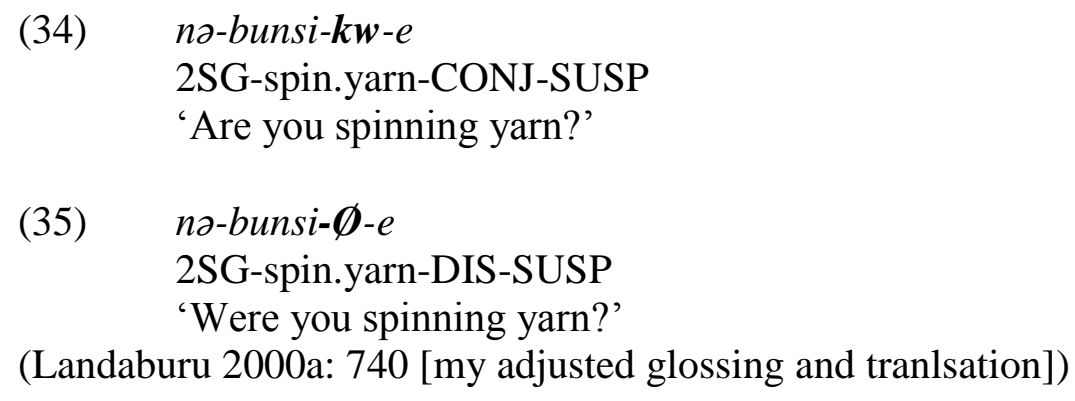

First person subject constructions with -in/ni (i.e. declarative), however, take the conjunct marker in both present and past contexts. 


$$
\begin{array}{ll}
a ̈ n-z o r i-w-a & n i \\
\text { 1SG-go-CONJ-PARTC.P } & \text { DECL } \\
\text { 'I'm going.' } &
\end{array}
$$

$$
\begin{aligned}
& \ddot{a} n-z o y-a \quad u \text { ' } \boldsymbol{k} w \text {-in } \\
& \text { 1SG-go-PARTC.Pdo-CONJ-DECL } \\
& \text { 'I went.' }
\end{aligned}
$$

(Ika Field notes 090823_Eli)

As stated in Section 5, the choice between conjunct/disjunct does not correspond to a difference in temporal perspective. One must instead consider this conveyed change in meaning as a result of the interaction between the conjunct/disjunct system and the three sentence mood suffixes -in, $-e$, and $-o$.

The difference in meaning encoded in examples (34) and (35) instead depends on the speaker's immediate access to an event. Given that the predicate (bunsi, 'spinning yarn') is the same in both examples, we may hypothesize that in (34), the speaker has immediate/present access to the event in question (i.e. that of spinning yarn) and expects the addressee to be able to provide first hand information on whether he/she presently is spinning yarn or not. "Access" should be understood here as denoting the speaker's ability to directly perceive, and in first person subject contexts, remember some event that either involves/involved the speaker or that he/she is/was in the immediate proximity of.

In examples (34) and (35), a separation is made between the speaker's conscious, present experience (potentially corroborated by the addressee) and his/her non-immediate access to a past event that still is first-hand information to the addressee as in (35), marking the former as conjunct and the latter as disjunct.

This situation is contrasted to examples (36) and (37) where a shift in terms of temporality is encoded in (37) by the auxiliary verb ( $a w$-, 'do') while keeping the conjunct marker in both contexts. Since the speaker's (first-hand) immediate access to some information is expressed by the conjunct marker, this is what we would expect for all constructions with first person subjects and conjunct marking regardless of temporal context.

The exclusive occurrence of conjunct $-w$ with first person and the combination of conjunct $k w$ with first and second person that was introduced in Section 4.1 and exemplified in examples (11) and (12), also serves to illustrate the notion of the speaker's immediate access to an event. From these examples and the ones in (36) and (37) we may conclude that there are two levels of immediacy that make up conjunct marking, one that denotes the direct perception of an event that involves the speaker and another that is less immediate in the sense that it marks an event as accessible to the speaker by memory or an event that is equally accessible to the speaker and the addressee, but where the epistemic authority is shifted towards the addressee. This hypothesis stems from the fact that the $-k w$ marker is the only conjunct form that combines with second person subjects and that $-k w$ is found in past contexts with first person subjects.

Conjunct marking is excluded with the future marker -ngwa in Ika, a feature that is consistent with the notion of immediate access, since events that have yet to happen are by definition inaccessible in the present. The non-combinability of future marking with conjunct is also reported by Dickinson (2000) for Tsafiki, where two out of four "future" markers only combine with the non-congruent (disjunct) in Dickinson's terms. In Tsafiki, a future marker that 
only combines with the disjunct, signals someone's intention to do something, but also that person's lack of control over the outcome (ibid: 416).

Further support for the proposed hypothesis in terms of access comes from the fact that interrogative constructions with first person subjects are obligatorily marked as disjunct. The loss of memory or the ignorance of the speaker with regard to some event/state that directly involves him/herself can only be expressed with disjunct marking in combination with $-o$, a feature that also applies to requests for non-first hand information (i.e. third person).

The second major issue that comes into play in analyzing the motivations underlying conjunct/disjunct marking in Ika is the semantic difference between - $e$ and $-o$, a distinction that is also conceptualized in terms of time perspective (see Section 4). Examples (30) and (31) are repeated here:

$$
\begin{array}{ll}
\begin{array}{l}
\text { kamə- } y-a \\
\text { dormir-DIS-PARTC.P }
\end{array} & \text { no } \\
\text { 'INTERR he asleep?' } & \\
& \\
\text { kamə-y- } a & \text { nar-e } \\
\text { dormir-DIS-PARTC.P } & \text { be-INTERR } \\
\text { 'Was he asleep?' } &
\end{array}
$$

(Landaburu 2000a: 742)

Since both (30) and (31) are disjunct, the semantic difference between them is not found in the speaker's immediate access to the event. That would require conjunct marking. The difference should instead be viewed in terms of an epistemic asymmetry between the speaker and the addressee with regard to the portrayed event.

The sentence in (30) asks for the addressee's present opinion or impression of the state of a third person. The lack of (active) participation/immediate access is indicated by disjunct marking and the interrogative - $o$ (in the form of $n o$ ) encodes the ignorance of the speaker, placing the epistemic authority entirely with the addressee.

Example (31), again, signals the speaker's non-access to the event in question, seen in the presence of the disjunct marker, but by marking the phrase with - $e$ the speaker also indicates that he/she has expectations on the event in question that may or may not be confirmed by the addressee. Depending partly on the context, example (31) encodes the speaker's expectation regarding the (third) person's present state but leaves it up to the addressee to confirm/deny this.

The 'suspensive' $-e$ is, as stated, not a true interrogative marker, but instead signals a common ground between the speaker and the addressee (from the perspective of the speaker), while at the same time leaving the "epistemic authority" with the addressee, thus conveying a question, while not encoding it. Consider examples (38) and (39), below:

$$
\begin{array}{lll}
\text { burro } & \text { na-né-chu- } \emptyset \text {-' } & \text { nár-e } \\
\text { donkey(Sp.) } & \text { 2SG-1SG.OBL-see-DIS-NEG } & \text { be-SUSP } \\
\text { 'Didn't you see my donkey? (I thought you did.)' (Sp. ¿no lo viste a mi burro?) }
\end{array}
$$


b chu-a uk-w-in

see-PARTC.P do-CONJ-DECL

'I saw it.' (Lo ví)

(39)a

eiy nä-chu-y-a nar-e

this 2SG-see-DIS-PARTC.P be-SUSP

'You've seen it (haven't you)?' (Sp. Sí, habias visto.)

$\mathrm{b}$ eiy chua-w-a nar-in

this see-CONJ-PARTC.P be-DECL

'Yeah, I've seen it' (Sp. Sí, lo habia visto)

(Ika Field notes 090822_Eli)

From the examples in (38) and (39) that were provided as examples of the use of $-e$, we see that $e$ is used in something like "tag-questions", featuring the expectations of the speaker. The fact that the question posed to the addressee is marked as disjunct is a consequence of referring to non-immediately accessible information from the point of view of the speaker, i.e. from a past event.

In contrast, $-o$ can be considered as a true interrogative marker because it encodes the speaker's ignorance, requesting information form the addressee. This asymmetric stance means that when the speaker poses a question to the addressee using the - $o$ suffix, he does so without conveying any expectations or previous assumptions. The non-access to an event is also encoded by the (obligatory) presence of the disjunct marker, regardless of person.

Further evidence for the proposed analysis of $-e$ comes from how it appears in elicitation. In eliciting declarative verb paradigms in all persons, one commonly gets the following forms starting with first person singular (a) through third person (c):

(40) a.

$\begin{array}{ll}k \ddot{a} m-\ddot{a} n & n u ́-k \boldsymbol{w} \text {-in } \\ \text { sleep-PARTC } & \text { be-CONJ-DECL }\end{array}$

'I'm asleep.'

b. käm-än nä-nu-kw-e

sleep-PARTC 2SG-be-CONJ-SUSP

'You are asleep(?)'

$\begin{array}{lll}\text { c. } & \text { käm-än } & \text { nug- } \boldsymbol{\emptyset} \text {-in } \\ \text { sleep-PARTC } & \text { be-DIS-DECL } \\ \text { 'He's asleep.' } & \end{array}$

(Ika Field notes 090822_Eli [my translation])

When asking for declarative verb phrases, i.e. without using intonation or other means to indicate a question, one would expect the form in (41) for second person subjects and not the one in (40b), above. 


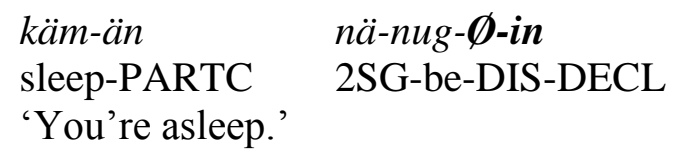

However, the form in (41) is rarely given unless specifically asked for. The reason is that the use of $-i n / n i$ with second person subjects results in a different meaning than one would anticipate from looking at it in terms of declarative vs. interrogative constructions.

In (42), the combination of second person subject and $n i$ is understood as a command:

$$
\begin{array}{lll}
m a & n \ddot{a}-z o y-\boldsymbol{\emptyset}-a & \boldsymbol{n i} \\
\text { 2SG.IND } & \text { 2SG-go-DIS-PARTC } & \text { DECL }
\end{array}
$$

'You go (i.e. you have to go!).'

This somewhat surprising consequence of combining -in/ni with a second person subject marker is in line with the analysis proposed here. -in/ni signals a speaker-asymmetry with regard to an event. The asymmetry in (42), however, is reversed when compared to -o/no, which although it also signals a form of asymmetry, is a request for information from the addressee. Example (42) is asymmetric in the sense that the speaker tells the addressee what to do by way of a command.

Proper imperative forms are formally apart from regular "declaratives" (they are uninflected for person), which means that (42) is not formally imperative, but that its meaning results from the use of $n i$ with second person subject marking, which places the initiative with the speaker. The example in (41) is thus better translated as 'you (will) sleep!', a translation that makes its absence from a "declarative paradigm" more understandable.

We have already seen that a combination of conjunct marking with first person subjects and the $-e$ marker does not result in a question posed to the subject him-/herself (Section 5, example 20). The use of conjunct marking with first person to form rhetorical questions as reported by Curnow (2002) for Awa Pit is not attested for Ika. The only (formal) way for the speaker to pose a question to himself is to use the -o/no indicating his/her own ignorance, asking the addressee for information.

By viewing conjunct/disjunct marking in terms of the speaker's immediate access to information and its interaction with the "modal" suffixes, -in/-e/-o, as signaling (a)symmetries between the speech participants, the connection between conjunct/disjunct marking and the -in/$e /-o$ suffixes, start to come into view. The set of available contrasts with conjunct and disjunct marking in Ika is illustrated in Figure 1:

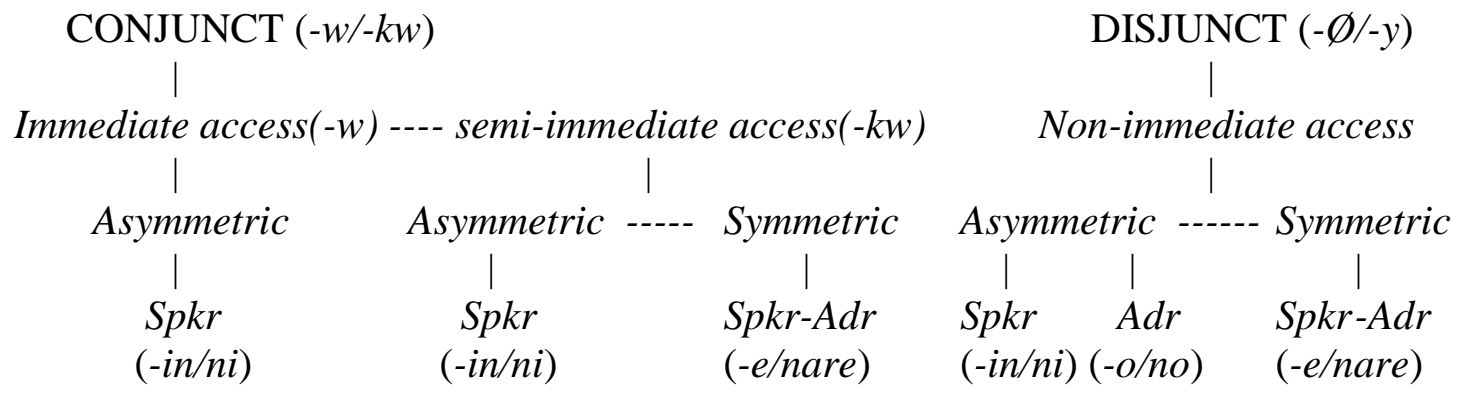

Figure 1: Interaction of person and epistemic assertion: access to information and knowledge asymmetry between the speech participants. 
With third person subjects, the asymmetries in figure 1 are also available although the semantics underlying the forms will not yield all available contrasts since they are never marked as conjunct. It is only in the interaction between the speaker and the addressee that the system can be fully accounted for.

We are thus in a position to finally state the underlying motivations behind conjunct/disjunct marking in Ika. Conjunct marking is used to indicate the speaker's immediate access to an event, something that can be done in two ways, either by signaling asymmetric access with first person subjects, or symmetrically with second person subjects. Regardless of which, the perspective is firmly rooted with the speaker, a fact that departs from the idea of viewing the addressee as the (sole) informant with conjunct marking. In Ika, a verb is marked as conjunct if the speaker has immediate access to an event that can also involve the addressee as the active subject, i.e. an inter-subjective evaluation. The two levels of accessibility indicated by $-w$ and $-k w$ above, aligns with the distribution of the $-e$ marker with second person subjects encoding a symmetry between the speaker and the addressee. This two-level split must be regarded as a consequence of linking conjunct/disjunct marking with the notion of (a)symmetry that is encoded in the sentence moodsuffixes.

Disjunct marking is used in all cases where the speaker lacks immediate access to an event either by way of memory or direct perception. Disjunct marking allows for an additional asymmetry distinction that is impossible with conjunct marking, namely one where the speaker signals his/her ignorance, leaving the epistemic authority with the addressee.

The proposed hypothesis is supported by a system of "complex-epistemic marking" in the closely related language Kogi, where the very same mechanics have produced a different system that complements the facts of conjunct/disjunct marking in Ika.

\section{Conclusion}

Conjunct marking originates in the indexical ground that is occupied by the speaker and the addressee as speaking subjects, encoding an intersubjective perspective. As an intersubjective assessment, conjunct marking signals an extension of the speaker's subjective perspective to allow for the inclusion of the addressee although the epistemic initiative (but not the authority) remains with the speaker. In a language like Ika, conjunct marking with second person subjects does not depend on an interrogative construction but is instead only possible with the suffix $(-e)$ that encodes a common ground between the speaker and the addressee. Depending on subject identity (first or second), this common ground shifts its focus on either the speaker or the addressee. The presence of (a)symmetries between the speech participants as a semantic feature of the conjunct/disjunct system in Ika is supported by the data from Kogi, which has developed a more detailed system that is less closely connected to grammatical person and thus resembles an independent qualification alongside e.g. evidentiality and tense.

The alignment/non-alignment between subject and speech-act participant that has been proposed as a core feature of conjunct/disjunct marking is put into question. From the point of view of the present analysis, this feature is a consequence of encoding first-hand information, either by way of stating it (speaker-subject) or by expecting someone to be able to supply it (addressee-subject). Encoding first-hand information has also been called "participatory-factual" (Rule 1977; Loughnane 2007) or "personal-factual" (Loughnane 2010) as part of evidential systems in Papuan languages such as Foe and Oksapmin. As evidentiality markers, participatory- 
factual forms are not tied to specific arguments, but the semantic basis must be seen as identical in both types of systems.

The role of the addressee in conjunct marking is blurred by using terms such as "informant" or "assertor", because in combining conjunct marking with second person subjects, the addressee as subject is not informing anyone of anything, it is the speaker who includes the addressee by way of charging him/her with the possibility of supplying first-hand information that directly involves the addressee. Failing to acknowledge the role of the addressee in conjunct/disjunct marking incidentally shows in the lack of attention to second person subject forms in formulating analyses of such systems (cf. Dickinson 2000, DeLancey 2001).

Several of the languages that feature the conjunct/disjunct pattern have conflated participatory-factual/first-hand semantics with conceptually related semantics that have a natural connection to information originating with the speech participants (see Section 3). In light of this, we may re-evaluate the functional core of conjunct/disjunct by comparing it to other epistemic qualification systems although the intersubjective nature of conjunct/disjunct marking sets it apart from both evidentiality and modality per se.

\begin{abstract}
Abbreviations:
1: first person, 2: second person, 3: third person, AFIRM: affirmative, ASSUR: assurative, asym.decl: asymmetrical declarative, asym.int: asymmetrical interrogative, BEN: benefactive, CNT: contrary to expectation, CONJ: conjunct, COP: copula, DAT: dative, DECL: declarative, DIS: disjunct, EXT: extra-locutive, FUT: future, HYP: hypothetical, IMP: imperfective, INT: intra-locutive, INTERR: interrogative, LIM: limitative, NEG: negative, NOM: nominalized, OBL: oblique, PARTC: participal, P: perfective(participal), PERF: perfective, PL: plural, PST: past, REFL: reflexive, SG: singular, SW: switch, sym.decl: symmetrical declarative, sym.int: symmetrical interrogative, SUSP: suspensive, TOP: topic
\end{abstract}

\title{
References:
}

Adelaar, Willem, F.H. \& Pieter C. Muysken 2004. The Languages of the Andes. Cambridge Languages Surveys. Cambridge: Cambridge University Press.

Bergqvist, Henrik. 2009. Field notes on Kogi, Ika, and Damana. Ms, Stockholm University. Bickel, Baltazar \& Johanna Nichols. 2007. Inflectional Morphology. In Language Typology and Syntactic Description: vol 3 Grammatical Categories and the Lexicon. Timothy Shopen (ed.) Cambridge: Cambridge University Press. 169-240.

Bickel, Baltazar. 2008 Verb agreement and epistemic marking: a typological journey from the Himalayas to the Caucasus. In Huber, B., M. Volkhart, \& P. Wildmer (eds.) Chomolangma, Demawend und Kasbek: Festschrift für Roland Bielmeier zu seinem 65 Geburtstag. 1-14. Halle:IITBS.

Creissels, Denis. 2008. Person variation in Akhvakh verb morphology: functional motivation and origin of an uncommon pattern. STUF, Berlin 61: 4, 309-325.

Creissels, Denis. 2009. Language documentation and verb inflection typology: the case of Northern Akhvakh (Nakh-Daghestanian). Handout at Chronos 9, Paris October 2-4 2009.

Curnow, J. Timothy. 2001. Why 'First/Non-First Person' is Not Grammaticalized Mirativity. Proceedings of ALS2k, the 2000 Conference if the Australian Linguistic Society. Keith Allan and John Henderson (eds.)

Curnow, J. Timothy. 2002. Conjunct/disjunct marking in Awa Pit. Linguistics 40 (3): 611-627. 
DeLancey, Scott. 1992. The historical status of the conjunct/disjunct pattern in Tibeto-Burman. Acta Linguistica Hafniensia 25: 39-62.

DeLancey, Scott. 2001. The Mirative and Evidentiality. Journal of Pragamtics 33 (3): 369-382.

Dickinson, Connie. 2000. Mirativity in Tsafiki. Studies in Language 24 (2): 379-421.

Frank, Paul. 1990. Ika Syntax. Studies in the Languages of Colombia 1. SIL: University of Texas at Arlington.

Hale, Austin. 1980. Person markers: finite conjunct and disjunct forms in Newari. In Trail R. (ed.) Papers in Southeast Asian Linguistics 7. Canberra: Pacific Linguistics. 95-106.

Hensarling, Grace. 1991. The function of -ki 'switch' in Kogi. Lingüistica Chibcha 10: 7-27.

Landaburu, Jon. 1988. El sistema de designación de la persona-sujeto en lengua ika. Amerindia 13 (45 Congrès des Américanistes):157-167

Landaburu, Jon. 1992. La langue ika ou Arhuaco : morphosyntaxe du verbe. Amerindia 17:1-30

Landaburu, Jon. 1994. La construction de la personne en trois étages; le système de la langue ika du nord de la Colombie. Faits de Langues 3

Landaburu, Jon. 2000a. La lengua ika. In Lenguas indígenas de Colombia : una visión descriptiva. Bogota: Instituto Caro y Cuervo.

Landaburu, Jon. 2000b. Clasificación de las Lenguas Indígenas de Colombia. In Lenguas indígenas de Colombia : una visión descriptiva. Bogota: Instituto Caro y Cuervo.

Loughnane, R. 2007. Expanding the Typology of Evidentiality: The Participatory/Factual in Oksapmin. Paper presented at the ALT 7 conference, Paris.

Loughnane, R. 2010. A Grammar of Oksapmin. PhD thesis. University of Melbourne. Lyons, John. 1977. Semantics vol. 2. Cambridge: Cambridge University Press.

Olaya Perdomo, Noel. 2000. Descripción preliminar del sistema verbal de la lengua kogi (o kawgi). In Gonzales de Peréz and Rodrigues de Montes (eds.) 781-87.

Ortíz Ricaurte, Carolina. 1994. Clases y Tipos de Predicados en la Lengua Kogui. In Landaburu (ed.) Estructuras sintacticas de la predicación: lenguas amerindias de Colombia. Bogotá: CCELA. pp 377-99.

Rule, W. M. 1977. A comparative study of the Foe, Huli and Pole languages of Papua New Guinea. Oceania Linguistic Monographs 20. Sydney, University of Sydney.

Tournadre, Nicholas. 1996. Comparaison des systèmes médiatifs de quatre dialectes tibétains (tibétain central, ladakhi, dzongkha et amdo). In Z. Guentchéva, (Ed.), L'énonciation médiatisée, Peeters: Paris. 195-213.

Trillos Amaya, Maria (1999) Damana. München: LINCOM EUROPA. 